\title{
SURVIVAL OF THE FIRST ANTI-TNF IN YOUNGER AND ELDERLY RHEUMATOID ARTHRITIS PATIENTS FROM BIOBADABRASIL REGISTRY
}

Rafael Mendonça da Silva Chakrr1,*, Markus Bredemeier², Ângela Duarte³, Marcelo Pinheiro, Bárbara Stadler Kahlow ${ }^{5}$, José Caetano Macieira ${ }^{3}$, Roberto Ranza 4 , José Roberto Silva Miranda ${ }^{6}$, Valeria Valim Cristo ${ }^{7}$, Gláucio Ricardo Werner de Castro ${ }^{8}$, Manoel Barros Bértolo ${ }^{9}$, Maria de Fátima Lobato da Cunha Sauma ${ }^{10}$, Vander Fernandes ${ }^{11}$, Ana Cristina de Medeiros Ribeiro ${ }^{12}$, Reginaldo Botelho Teodoro ${ }^{13}$, Claiton Viegas Brenol ${ }^{1}$, Deborah Negrão Gonçalo Dias ${ }^{14}$, Hellen Mary da Silveira de Carvalho ${ }^{15}$, Samia Araujo de Sousa Studart ${ }^{16}$, Geraldo da Rocha Castelar Pinheiro ${ }^{17}$, Laurindo Ferreira da Rocha ${ }^{18}$, Ivânio Alves Pereira ${ }^{19}$, Morgana Ohira Gazzeta ${ }^{20}$, Adriana Maria Kakehasi ${ }^{14}$, Paulo Louzada-Júnior ${ }^{21}$, André Luiz Shinji Hayata ${ }^{22}$, Fabiana Pompeo de Pina $^{23}$, Cristiano Michelini Lupo ${ }^{24}$, Lidia Balarini', Inês Guimarães da Silveira ${ }^{25}$, Sérgio Candido Kowalski ${ }^{26}$, David Cezar Titton ${ }^{26}$, Aline Ranzolin²7, leda Maria Magalhães Laurindo ${ }^{28}$, Ricardo Machado Xavier ${ }^{1}$

1.Universidade Federal do Rio Grande do Sul, Porto Alegre (RS), Brazil; 2.Hospital Nossa Senhora da Conceição, Porto Alegre (RS), Brazil; 3.Universidade Federal de Sergipe, Aracaju (SE), Brazil; 4.Universidade Federal de Uberlândia, Uberlândia (MG), Brazil; 5. Hospital Universitário Evangélico de Curitiba, Curitiba (PR), Brazil; 6.Artrocenter Clínica Médica de Taubaté, Taubaté (SP), Brazil; 7.Universidade Federal do Espírito Santo, Vitória (ES), Brazil; 8.Hospital Governador Celso Ramos, Florianópolis (SC), Brazil; 9.Universidade Estadual de Campinas, Campinas (SP), Brazil; 10.Universidade Federal do Pará, Belém (PA), Brazil; 11.Universidade de Cuiabá, Cuiabá (MT), Brazil; 12.Universidade de São Paulo, São Paulo (SP), Brazil; 13.Universidade Federal do Triângulo Mineiro, Uberaba (MG), Brazil; 14.Universidade Federal de Minas Gerais, Belo Horizonte (MG), Brazil; 15. Hospital de Base do Distrito Federal, Brasília (DF), Brazil; 16. Hospital Geral de Fortaleza, Fortaleza (CE), Brazil; 17.Universidade do Estado do Rio de Janeiro, Rio de Janeiro (RJ), Brazil; 18.Universidade Federal de Pernambuco, Recife (PE), Brazil; 19.Universidade do Sul de Santa Catarina, Florianópolis (SC), Brazil; 20.Santa Casa de Misericórdia do Rio de Janeiro, Rio de Janeiro (RJ), Brazil; 21.Universidade de São Paulo, Ribeirão Preto (SP), Brazil; 22.Clínica de Reumatologia de Osasco, Osasco (SP), Brazil; 23.Universidade Federal de Goiás, Goiânia (GO), Brazil; 24.Faculdade de Medicina de São José do Rio Preto, São José do Rio Preto (SP), Brazil; 25.Pontifícia Universidade Católica do Rio Grande do Sul, Porto Alegre (RS), Brazil; 26.Universidade Federal do Paraná, Curitiba (PR), Brazil; 27.Universidade de Pernambuco, Recife (PE), Brazil; 28.Universidade Nove de Julho, São Paulo (SP), Brazil.

*Corresponding author: rchakr@hcpa.edu.br

\section{BACKGROUND}

Analysis of drug survival can provide useful information on treatment effectiveness and safety in rheumatic diseases, including rheumatoid arthritis (RA). The aim of the present study is to report the survival of the first anti-TNF agent in RA patients younger and older than 65 years of age.

\section{METHODS}

BiobadaBrasil is a multicentric, registry-based cohort study of Brazilian patients with rheumatic diseases starting their first biologic disease modifying antirheumatic drug. The present analysis includes patients with RA, recruited from January 2009 to October 2019, followed-up over the first course of treatment with an anti-TNF agent until censoring (latest date, November 19, 2019) or occurrence of the outcome of interest (interruption of treatment). Treatment course is defined as a period during which the medication scheme does not change. The primary outcome was the interruption of treatment course for any reason (except for pregnancy or disease remission); interruption of treatment due to adverse events/death and due to inefficacy served as secondary outcomes. Multivariable Cox proportional hazard models were applied.

\section{RESULTS}

In total, 1,011 RA patients from 27 Rheumatology centers (3,333.90 patient-years [PY]) were enrolled: 900 (2,980.72 PY) $<65$ years old and 111 ( $353.18 \mathrm{PY}) \geq 65$ years old. Adalimumab was the most frequently prescribed agent in younger and older patients ( $n=321$ and $n=33$, respectively), followed by infliximab ( $n=236$ and $n=31)$ and etanercept $(n=226$ and $n=31)$. The overall incidence of treatment interruption was 18.4/100 PY (younger =18.3/100 PY; older =19.0/100 PY; adjusted hazard ratio for older, $1.09[95 \% \mathrm{Cl}=0.83-1.43])$. The hazard ratios of the primary and secondary outcomes according to anti-TNF agent in both subgroups are in Table 1.

Realização: 
Table 1. Hazard ratios (HR) of interruption of therapy course of each therapeutic agent (the reference category is infliximab). Results are $\mathrm{HR}, 95 \% \mathrm{Cls}$, and $\mathrm{P}$ values*.

\begin{tabular}{|c|c|c|c|}
\hline \multicolumn{4}{|c|}{ RA patients $<65$ years old } \\
\hline Agent (number of patients) & $\begin{array}{l}\text { Interruption of treatment for any } \\
\text { reason ( } 545 \text { events) }\end{array}$ & $\begin{array}{l}\text { Interruption of treatment due } \\
\text { to adverse events or death } \\
\text { (156 events) }\end{array}$ & $\begin{array}{l}\text { Interruption of treatment due } \\
\text { to inefficacy ( } 279 \text { events) }\end{array}$ \\
\hline Adalimumab (321) & $0.90(0.73-1.11), P=0.325$ & 0.74 (0.51-1.08), $P=0.114$ & 1.10 (0.82-1.49), $P=0.520$ \\
\hline Etanercept (226) & $0.83(0.66-1.05), P=0.113$ & $0.54(0.34-0.84), P=0.006$ & $0.94(0.68-1.31), P=0.719$ \\
\hline Certolizumab/Golimumab (117) & $0.75(0.50-1.10), P=0.146$ & $0.37(0.16-0.83), P=0.016$ & $1.02(0.60-1.73), P=0.957$ \\
\hline \multicolumn{4}{|c|}{ RA patients $\geq 65$ years old } \\
\hline Agent (number of patients) & $\begin{array}{l}\text { Interruption of treatment for any } \\
\text { reason ( } 67 \text { events) }\end{array}$ & $\begin{array}{l}\text { Interruption of treatment due } \\
\text { to adverse events or death } \\
\text { ( } 25 \text { events) }\end{array}$ & $\begin{array}{l}\text { Interruption of treatment due } \\
\text { to inefficacy (19 events) }\end{array}$ \\
\hline Adalimumab (33) & $0.41(0.19-0.86), P=0.019$ & $0.22(0.05-0.90), P=0.035$ & $0.43(0.09-2.01), P=0.285$ \\
\hline Etanercept (31) & $0.68(0.32-1.41), P=0.296$ & $0.61(0.17-2.16), P=0.445$ & $0.47(0.10-2.24), P=0.344$ \\
\hline Certolizumab/Golimumab (16) & $0.97(0.35-2.71), P=0.950$ & $0.61(0.10-3.84), P=0.594$ & 6.69 (0.79-56.47), $P=0.081$ \\
\hline
\end{tabular}

\section{CONCLUSION}

In BiobadaBrasil, the risk of treatment interruption with anti-TNF agents is not significantly higher in older individuals. Anti-TNF interruption due to adverse events or death among RA patients $<65$ years old was lower for etanercept and certolizumab/golimumab compared to infliximab, while among RA patients $\geq 65$ years old the overall risk was lower for adalimumab compared to infliximab with a reduced risk of interruption due to adverse events.

\section{KEYWORDS}

Rheumatoid arthritis, Anti-TNF, Survival, Persistence. 